\author{
VÍT VOŽENÍLEK
}

\title{
TERRAIN SENSITIVITY IN ENVIRONMENTAL MODELS
}

V. Vož e níle k: Terrain Sensitivity in environmental models. - Geografie - Sborník CGGS, 107, 2, pp. 111 - 120 (2002). - Environmental models involved many spatial components. A terrain (Earth's surface) is often included as crucial factor of modelled processes. Terrain is a continuous phenomenon that is represented by various discrete or networked means. This dimensional variability in representation process impacts in both inherent terrain parameters (incl. surface forms) and modelled outcomes. The paper treats various aspects and shows them in examples.

KEY WORDS: Environmental models - terrain sensitivity - GIS - digital terrain models.

\section{Introduction}

Environmental processes often have a signsificant horizontal component in a landscape that is neglected in current environmental models, i.e. lateral stream erosion, which by widening a valley can significantly alter the depositional geometry within a floodplain over geologic time. A terrain (Earth's surface) is mostly involved in the models.

There is a dynamic relationship between the surface forms and the processes that build, modify or remove the surface forms. The processes include some form of displacement of the Earth's surface material, which varies in relation to velocity, direction, amount of material removed and the frequency or return period of the process. This gradually changes topography. The terrain changes can be quantified by comparing altitude and different terrain parameters, which have a geomorphic significance with respect to terrain changes.

Terrain sensitivity is an ability of terrain to impact all supplemental and derived topics in terrain processing. Terrain sensitivity is caused by influences of Earth's surface representation in digital data models.

\section{Digital terrain models}

Digital terrain models (DTMs) are digital representations of the terrain properties at discrete points in that landscape (Moore, Nieber 1989). These models have been designed recently to calculate the distributed topographical attributes of the landscape for use in environmental sciences, geography, cartography, mining, land-use planning, engineering, defence etc.

Terrain is a „continuous“ phenomenon and potentially has an infinite number of points, which can be measured. Obviously it is impossible to record every point. Consequently, a sampling method must be used to extract representative points to build a surface model that approximates the actual surface. Many 
environmental phenomena are related to terrain (runoff, agriculture etc.). The environmental models including DEM should (Voženílek 1996):

- accurately represent the surface,

- be suitable for efficient data collection,

- minimise data storage requirements,

- maximise data handling efficiency,

- be suitable for surface analysis.

A digital terrain model may be defined as a regular gridded matrix of elevation values that represents surface form called a grid. There is less certainty in the way in which the DTM should be interpreted as a model of continuous surface form. The process of interpolating parts of surfaces from point values in a DTM is fundamental to much DTM processing and analysis, yet the implications of the form of interpolation are not always fully appreciated.

The TIN model is a vector topological structure similar in concept to the fully topologically defined structures for representing polygon networks. The TIN model regards the nodes of the network as primary entities in the database. The topological relations are built into the database by constructing pointers from each node to each of its neighbouring nodes. The neighbour list is store clockwise around each node starting at north.

TIN data structure offers the best approximation of a real terrain surface. There are two reasons for this. Firstly, every measured data point is being used honoured directly, since they form the vertices of the triangles used to model the surface, to determinate the heights of additional points by interpolation and to carry out the construction of contours. Secondly, the use of triangles offers a relatively easy way of incorporating breaklines, faultlines and other natural linear hypsographical objects.

Digital terrain models based on TINs allow for variable spatial resolution, lend themselves naturally to interpolation procedures and make dynamic rediscretization a real possibility. However, use of TIN-based dynamic models has not been widespread, in part because of the increased complexity of data structures and algorithm development in a TIN framework (see Fig. 1).

In recent years, spatially distributed models of land surface processes, such as runoff and erosion, have come into widespread use in the Earth and environmental sciences. As these models grow in sophistication, the software engineering effort required to implement them also expands. Therein lies the need for portable, modular codes that can implement many of the basic requirements of a distributed model in a flexible, efficient, and applicationindependent manner.

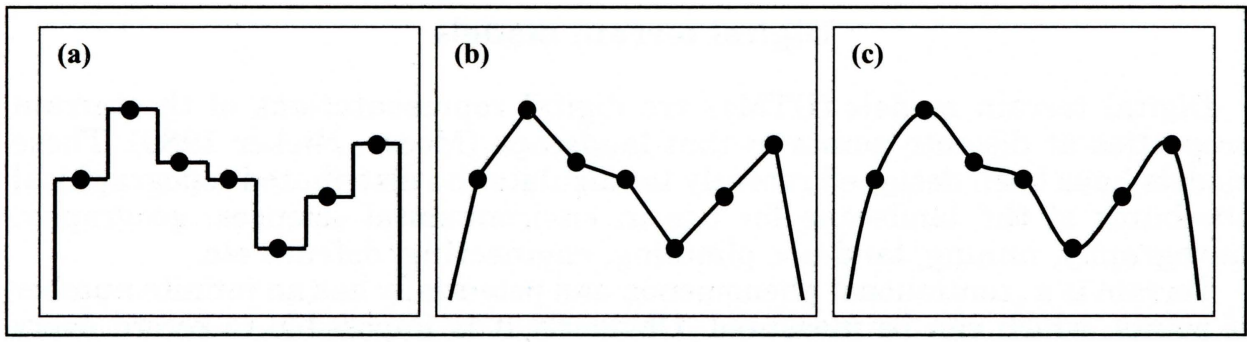

Fig. 1 - Three forms of interpolation used to transform discrete DEM cell values into continuous surface models. (a) Proximal interpolation; (b) linear interpolation; (c) cubic spline interpolation. (Wood 1999) 


\section{Terrain data}

An analysis of scaling effects in DTMs evaluates whether data aggregation is a useful spatial tool or whether it leads to an unacceptable loss of information. Some issues concern the appropriate resolution of DTMs used to derive surface input parameters for environmental models. Investigations involving commercially available terrain data sets with different horizontal and vertical resolutions and systematically aggregated DTMs were presented in many papers, for example, deriving a stream network and the contributing subareas from a DTM with a distinct critical support area. By varying this threshold area various watershed configurations were obtained. Terrain data with different resolutions diverge in landscape representation and in the derived parameters such as slopes, flow directions and channel networks. Coarse DTMs show a smoother terrain and shorter flow paths than highly resolved data. The contributing threshold area controls the extent of the watershed configuration and therefore determines the drainage density. These topographic and geomorphological features help to explain differences in the runoff simulation results. Watershed configurations with a varying extent of the channel network can be derived from a distinct DTM. These can then be used to simulate surface runoff and the drainage densities of the configurations correlated with the simulated runoff volume. A distinct drainage density, however, does not necessarily lead to similar simulation results when different DTMs are used. For example, since the hydrological model permits reinfiltration, the runoff volume depends directly on the lengths of the overland flow. Therefore, the mean length of the overland flow paths might to a certain degree be considered as a scaling factor.

Catchment boundary interpretation using topographical maps depends upon the representation of both altitude and water features. The level of details of the topographic map is dependent upon the scale of mapping and the compilation guidelines used by the mapping organisation. Thus, the source map accuracy is known as it is a reliable guide to overall accuracy (Miller et al. 1996).

Remote sensing data of the Earth's surface is readily available in digital format. These data are used for identifying certain features of interest in the image with the assistance of computers. To identify a feature of interest we not only have to classify individual pixels as belonging to a specific class, but also identify a set of such pixels as a part of the feature.

Developments in digital photogrammetry have provided the ability to automatically generate DTMs. Using overlapping imagery, dense grids of coordinates can be collected at high speeds ( 150 points per second) with a high level of accuracy. The trend towards using PC-based hardware, the widespread use of GIS, and the forthcoming availability of high-resolution satellite imagery over the Internet at ever-lower costs means that the use of automated digital photogrammetry in terrain modelling is likely to become more widespread.

\section{Distributed models}

Distributed models of surface processes such as runoff, vegetation growth, soil erosion, forest fires, landscape evolution, and other processes typically share a number of important features in common. All involve (Voženílek 1996): 
- spatial division of terrain into discrete elements,

- storage of mass and/or energy within landscape elements,

- routing of flows of mass (e.g., water) and/or energy among landscape elements,

- dynamic updating of boundary conditions (e.g., rainfall input), and

- dynamic updating of state variables (e.g., soil moisture and surface elevation) through time.

Often, the programming effort required to implement these features is nontrivial and quite labour intensive, especially when the underlying spatial representation is irregular. For example, the case of models based on triangulated irregular networks. Although current GIS systems provide sophisticated capabilities for spatial representation of data, performance and other limitations make them unsuitable for computationally intensive dynamic (i.e., time evolving) simulations. Thus, to reduce software development times and minimise duplication of effort, it would be advantageous to develop application-independent modelling routines that would provide the underlying space and time structure for distributed models without dictating the processes or state variables.

\section{D spatial data models}

3D spatial data models (i.e. based on the National Imagery and Mapping Agency's (NIMA) Vector Product Format (VPF)), are capable of supporting high-resolution $3 \mathrm{D}$ representations of natural and man-made environments with full 3D topology. The assumption that terrain has a single value at a specified 2D location does not necessarily hold true. Structures such as bridges, overpasses, tunnels, and the interiors of buildings cannot be adequately represented using $2 \mathrm{D}$ topology. Therefore, a spatial data model that supports 3D topology is needed.

Some previous work in the development of data models that support 3D topology, from both the GIS and computer graphics communities have been processed.

\section{Surface forms}

Many environmental models have been developed over the past decades. However, relatively little is known about handling the effects of changing spatial and temporal resolutions (Wood 1999). Therefore, resolution effects remain a factor of uncertainty in many environmental modelling approaches. In multi-scale studies of landscape process modelling an emphasis lays on quantifying the effect of changing the spatial resolution upon modelling the spatial processes (Schoorl, Sonneveld, Veldkamp 2000). Theoretical digital terrain models eliminate effects of landscape representation. The only variable factors can be DTM resolution and the method of flow routing, both steepest descent and multiple flow directions. The general trend was an increase of erosion predictions with coarser resolutions. An artificial mathematical overestimation of erosion and a realistic natural modelling effect of underestimating resedimentation is the cause of this. Increasing the spatial extent eliminates the artificial effect while at the same time the realistic effect is enhanced. Both effects can be quantified. They increase 
within natural landscapes. The modelling of landscape processes benefits from integrating all types of results at different resolutions.

Wolock and McCabe (2000) compared terrain characteristics computed from 100 - and $1000-\mathrm{m}$ resolution DEM data for 50 locations representing varied terrain in USA. The topographic characteristics were three parameters used extensively in hydrological research and modelling - slope, specific catchment area and a wetness index computed as the logarithm of the specific catchment area divided by slope. Slope values computed from 1 000-m DEMs were smaller than those computed from 100-m DEMs. Specific catchment area and the wetness index were larger for the $1000-\mathrm{m}$ DEMs compared with the 100m DEMs. Most of the differences between the 100- and $1000-\mathrm{m}$ resolution DEMs were attributed to terrain-discretization effects in the computation of the topographic characteristics and were not the result of smoothing or loss of terrain detail in the coarse data. The differences in the average values of the topographic characteristics computed from $100-$ and $1000-\mathrm{m}$ resolution DEMs were predictable; that is, biases in the mean values for the characteristics computed from a $1000-\mathrm{m}$ DEM can be corrected with simple linear equations.

Drainage density defined as the total length of channels per unit area, is a fundamental property of natural terrain that reflects local climate, relief, geology, and other factors. Accurate measurement of drainage density is important for numerous environmental applications, yet it is a difficult quantity to measure, particularly over large areas. Tucker, Catani, Rinaldo and Bras (2001) developed a method for generating maps of drainage density using digital elevation data. The method relies on measuring hillslope flow path distance at every unchanneled site within a basin and its analysing as a random space function. As a consequence, they measured not only its mean (which is half the inverse of the traditional definition of drainage density) but also its variance, higher moments, and spatial correlation structure. This yields a theoretically sound tool for estimating spatial variability of drainage density. Averaging length-to-channel over an appropriate spatial scale also makes it possible to derive continuous maps of drainage density and its spatial variations. The study showed that the autocorrelation of length scale provides a natural and objective choice for spatial averaging. This mapping technique was applied to a region of highly variable drainage density in the Northern Italy. The method is capable of revealing large-scale patterns of variation in drainage density that are correlated with lithology and relief. The method provides a more general way to quantitatively define and measure drainage density to test geomorphic models, and to incorporate drainage density variations into regional-scale hydrologic models.

\section{Environmental models with DTM}

Digital terrain models make it possible to quantify a topographic surface. When new DEMs are generated from the same topographic surfaces with certain increment in time it is possible to achieve measures of horizontal and vertical surface displacement. The quantification of horizontal displacements involves large computational efforts if the aim is the analysis of spatially distributed velocity vectors (Etzelmuller 2000). The analysis of vertical surface changes results in measures of the magnitude of vertical surface changes and how vertical changes are distributed spatially over the topographic surface studied. 


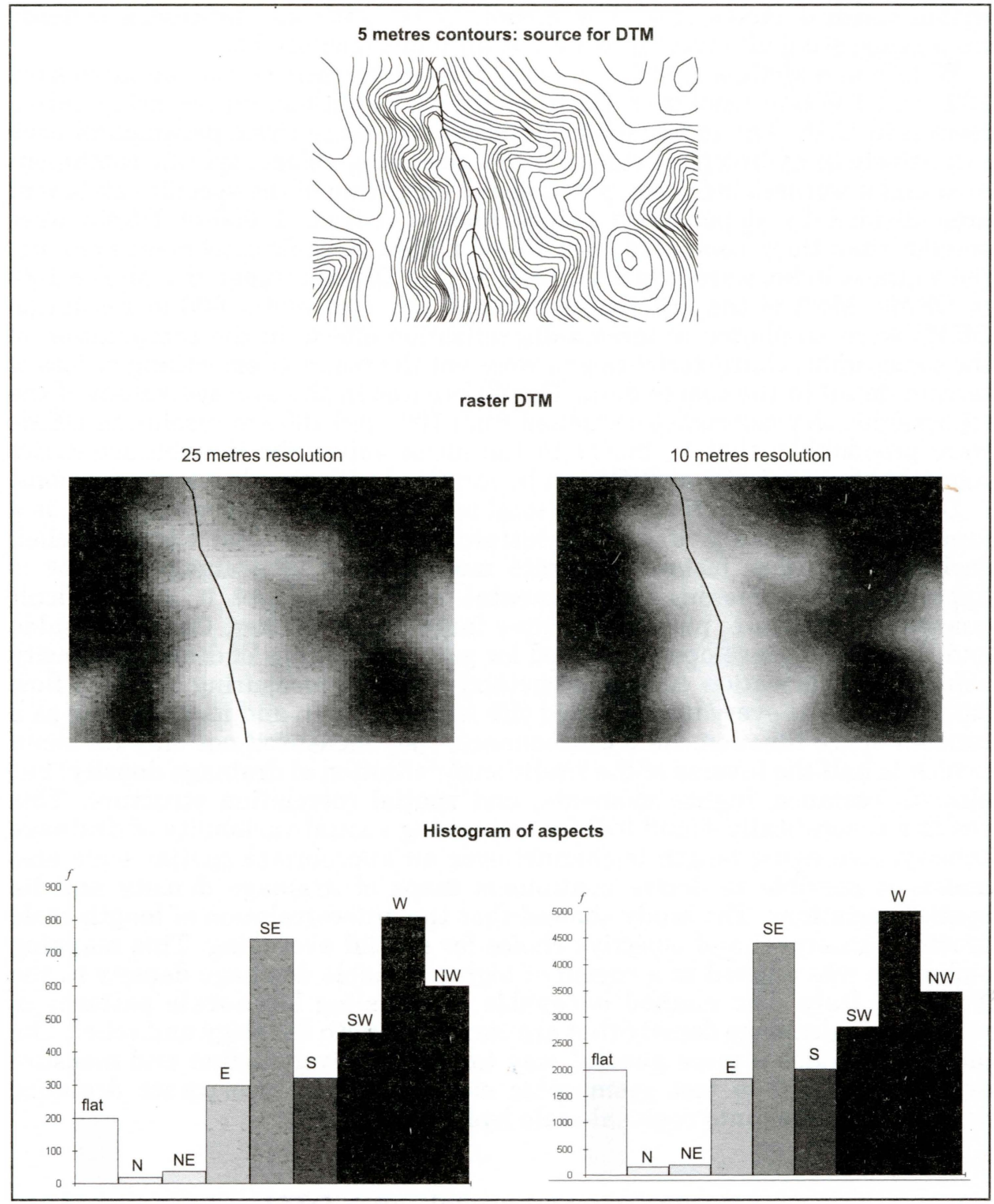

Fig. 2 - Terrain sensitivity through aspects derived from two different DTMs generated over one data source

Terrain sensitivity depends upon many phases in process of DTM generating - grid resolution, interpolation methods, parameters of interpolation etc. (Wood 1999). Figure two shows terrain sensitivity through aspects derived from two different DTMs generated over one data source. The impact is distinct form histograms (see Fig. 2).

Various quantitative environmental methods have been developed for characterising the morphology of surface (surface forms) (Evans 1972, Mark 1975, Elghazali and Hassan 1986, Fels 1995, Wood 1999, Voženílek 1996) and 
for extracting hydrologic characteristics from DEMs (Jenson and Domingue 1988). However, since classifications of surface forms are not based on morphology alone but also on the position of the land surface in relation to its surroundings.

A method for land classification yields a quantitative index of landscape position by evaluating elevation differences between a given point and other model points within a specified search radius. The value calculated is the mean of the distance-weighted elevation differences between a given point and all other model points within a specified search radius. Greater positive values indicate lower topographic positions (proximal to streams) and greater negative values indicate higher landscape positions (ridges, summits) while values approaching zero indicate mid-slope positions. Where relief is minimal within the search radius, values will also tend to approach zero. The extent of the search area is an important consideration, since the evaluation of position is most meaningful when confined to a single landform. In principle, the radius of search should be one-half of the fractal dimension of the landscape, that is, one half of the ridge-to-stream distance in that landscape. Under such circumstances, a point located at mid-slope position is evaluated with respect to points extending from the stream at the bottom of the slope to the ridge at the top of the slope. Average ridge-to-stream distance varies considerably among different landscapes but is consistent within a particular region. Estimates of ridge-to-stream distance are obtained for the various regions by visualising digital terrain models within each region, measuring ridge-tostream distance for a number of typical surface forms, and taking the mean of these measurements to obtain a representative value.

\section{Impacting of terrain sensitivity to modelled results}

An important component of the modelling approach are the digital terrain models that form the basis of the Earth's surface and stream networks that are used to derive many spatial parameters. It is also important to estimate the influence the importance of these parameters and to calibrate the model accordingly (Wheeler, 1993). The sensitivity of surface runoff simulations to watershed configurations can be studied with synthetic storms and by means of an infiltration excess runoff model.

The main source for catchment-wide terrain models in the Czech Republic are contours digitised from 1:10 000 paper maps at contour intervals of $1-5$ metres. There are a number of options for the production of a DTM from digitised contours, including triangulated irregular networks, inverse distance weighting or kriging. Each of the methods themselves have a number of options available, such as a choice of algorithms, the value of controlling parameters and the selection of spatial lags and resolutions. There are questions how faithfully these methods represent the environment (Maidment 1996) and how they influence modelling results. This has resulted in a requirement for systematic studies into the most suitable terrain representation to use in conjunction with other spatial datasets (Maidment 1993). In general, a sensitivity analysis establishes the effect of the different available techniques on any model outputs. The analysis takes into account a representative range of the current terrain modelling techniques available and their interaction with different surface forms. The results of the analysis can be used to make an appropriate selection of techniques for DEM 
production for many regions, and to give an indication of the sensitivity of the environmental hazard models to errors and generalisations due to the DEM. It is envisaged that the information gained from sensitivity analysis provides a useful set of guidelines for future projects that wish to use these techniques.

Most studies on the use of physically based hydrological models have identified saturated hydraulic conductivity as one of the most sensitive input parameters. However, it is also one of the most difficult landscape properties to measure accurately, casting doubt on the ability of modellers to estimate this parameter for catchment simulations. Several studies have shown that conductivity estimates are greatly influenced by the measurement method used, primarily because of scale effects (Beven ed. 1997). The effect of conductivity measurement method can be evaluated on catchment simulations aimed at predicting water yield from forested catchments. Method highlights the need for caution when applying soil hydraulic measurements to catchment-scale models (Davis, Vertessy, Silberstein 1999).

Terrain sensitivity depends upon grid size of raster DTMs which influences the representation of drainage areas and local slopes derived from DTMs. Catchments tend to increase and local slope decreases with increasing grid size. For example different grid size DTMs created from the contours illustrate profound shifts in the spatial distribution of predicted landslide hazards (Montgomery, Dietrich, Sullivan 1998).

\section{Conclusion}

With the increasing use of GIS and availability of DTMs, the quantification of surface changes is of high interest, not only in geomorphology. Surface changes are normally estimated by taking the differences of more DTMs, which is a complicated operation with respect to error propagation. Thus, high-resolution DTMs with high accuracy are necessary to derive statistically reliable differential surfaces that give a spatial picture of surface changes. In the case of low magnitude geomorphologic changes or poorer DTM quality, spatial averaging and statistical analysis are suitable to estimate surface changes, at least quantitatively. The principles of terrain parameterisation and landform classification are very useful in the analysis of surface changes.

DTM grid size fundamentally constrains the role of physically based models in real environments. However, minor misrepresentation of terrain common in DTMs can seriously impact the predictions of environmental process models. The headwaters, for example, can flow into different watershed. Reducing the elevation of a single pixel in the original raster DTM corrects misrepresentation. In general, the terrain-discretisation effects are greatest on flat terrain with long length-scale features, and the smoothing effects are greatest on steep terrain with short length-scale features.

Uncertainty in the compilation of altitude or hydrological details on the source map influences the quality of the interpretation of a catchment boundary. Thus, the principle is that reliability of the boundary delimitation ultimately depends upon the integrity of the map, either in graphical or digital form. Validity of the boundary interpretation can also vary according to the land cover and land use.

The level of generalisation of the contours has a significant impact on the reliability with which a boundary may be delimited. Aggregation methods, aggregation level and the geometry of source data cause considerable 
differences in estimating of surface forms, environmental characteristics and ultimately affect the various model outputs.

\section{References:}

BEVEN, K. J., ed. (1997): Distributed Modelling in Hydrology: Applications of TOPMODEL, Wiley, Chichester, $261 \mathrm{p}$.

DAVIS, S. H., VERTESSY, R. A., SILBERSTEIN, R. P. (1999): The sensitivity of a catchment model to soil hydraulic properties obtained by using different measurement techniques. Hydrological Processes, 13, No. 5, pp. 677-688.

ELGHAZALI, M. S., HASSAN, M. M. (1986): A simplified terrain relief classification from DEM data using finite differences. Geo-Processing 3, pp. 167-178.

ETZELMULLER, B. (2000): On the Quantification of Surface Changes using Grid-based Digital Elevation Models (DEMs). Transactions in GIS, 4, No. 2, pp. 129-143.

EVANS, I. S. (1972): General geomorphometry, derivations of altitude, and descriptive statistics. Spatial Analysis in Geomorphology, ed. Chorley, R. J. New York: Harper and Row.

FELS, J. E. (1995): Landscape Position and Classified Landtype Mapping for the Statewide DRASTIC Mapping Project. Raleigh, NC: North Carolina State University. Technical report to the North Carolina Department of Environment, Health, and Natural Resources, Division of Environmental Management.

JENSON, S. K., DOMINGUE, J. O. (1988): Extracting topographic structure from digital elevation data for geographic information system analysis. Photogrammetric Engineering and Remote Sensing 54, pp. 1593-1600.

MAIDMENT, D. R. (1993): GIS and Hydrologic Modeling. Environmental Modeling with GIS. Goodchild, M. F., Parks, B., O., Steyaert, L. T. (eds.). New York: Oxford University Press, pp. 147-167.

MAIDMENT, D. R. (1996): Environmental Modeling within GIS. GIS and Environmental Modeling: Progress and Research Issues. Goodchild, M. F., Steyaert, L. T., Parks, B. O., Johnston, C., Maidment, D., Crane, M., Glendinning, S. (eds.). Boulder: GIS World Books, pp. 315-324.

MARK, D. M. (1975): Geomorphometric parameters: a review and evaluation. Geografiska Annaler 3-4, Series A, pp. 165-177.

MILLER, D. et al. (1996): The assessment of catchment environmental characteristics and their uncertainty. Inovation in GIS 3, Taylor ( Francis, London, pp. 55-62.

MONTGOMERY, D. R., DIETRICH, W. E., SULLIVAN, K. (1998): The Role of GIS in Watershed Analysis. In: Lane, S. N., Richards, K. S., Chandler, J. H. (eds): Landform Monitoring, Modelling and Analysis, John Wiley ( Sons Ltd., pp. 241-261.

MOORE, I. D., NIEBER, J. L. (1989): Landscape Assessment of Soil Erosion and Nonpoint Source Pollution. Journal of Minnesota Academy of Science, 55, No. 1, pp. 18-25.

SCHOORL, J. M., SONNEVELD, M. P. W., VELDKAMP, A. (2000): Three-dimensional landscape process modelling: the effect of DEM resolution, Earth Surface Processes and Landforms, 25, No. 9; pp. 1025-1034.

THIEKEN, A. H., LÜCKE, A., DIEKKRÜGER, B., RICHTER, O. (1999): Scaling input data by GIS for hydrological modelling. Hydrological Processes, 13, No. 4, pp. 611-630.

TUCKER, G. E, CATANI, F., RINALDO, A., BRAS, R. L. (2001): Statistical analysis of drainage density from digital terrain data. Geomorphology, 36, No. 3-4, pp. 187-202.

WHEELER, D. J. (1993): Commentary: Linking Environmental Models with Geographic Information Systems for Global Change Research, Photogrammetric Engineering and Remote Sensing, 59, No. 10, October 1993, pp. 1497-1501.

WOLOCK, D. M., MCCABE, G. J (2000): Differences in topographic characteristics computed from $100-$ and $1000-\mathrm{m}$ resolution digital elevation model data. Hydrological Processes, 14, No. 6, pp. 987-1002.

VOŽENÍLEK, V. (1996): Fundament of Digital Elevation Model as a Tool for Geomorphological Research. Acta Univ. Palacki Olomouc, Fac. rer. nat. (1996) Geographica, 34 .

WOOD, J. D. (1999): Modelling the Continuity of Surface Form Using Digital Elevation Models. In Poiker, T., Chrisman, N. (eds) Proceedings, 8th International Symposium on Spatial Data Handling, pp. 725-736. 


\section{CITLIVOST RELIÉFU V MODELECH ENVIRONMENTÁLNÍCH JEVU゚}

Citlivost reliéfu (terrain sensitivity) je schopnost reliéfu ovlivnit všechny prvky v procesu zpracování reliéfu. Citlivost reliéfu je způsobena generalizovaným vyjádřením zemského povrchu v digitálních datových modelech.

Většina environmentálních jevů je $\mathrm{v}$ krajině přímo nebo nepřímo vázána na zemský povrch. Při jejich simulaci v modelech různé abstrakce a různé podrobnosti dochází k ovlivnění výstupủ vlastnostmi vyjádření reliéfu v modelu, tzn. jeho citlivostí. Tyto environmentální modely využívají digitální reprezentace reliéfu $\mathrm{v}$ digitálních modelech reliéfu (DMR). Běžně jsou využívány oba základní druhy DMR, to rastrový grid i vektorový TIN. Citlivost reliéfu $\mathrm{v}$ modelech environmentálních jevủ závisí na všech fázích zpracování povrchu, počínaje výběrem zdrojových dat přes stanovení rozlišení, interpolačních metod a jejich parametrů atd.

Environmentální modely obsahují také nejrůznější odvozené parametry, např́íklad morfometrické charakteristiky a tvary reliéfu. Řada studií (např. Wolock, McCabe 2000, Tucket a kol. 2001) diskutuje o vhodnosti užití zdrojových dat pro vyjádření reliéfu. Jsou však uvažovány již generalizované zdroje výškových dat (vrstevnice), zatímco $\mathrm{k}$ přesnějšímu vyjádření reliéfu a ke snížení vlivu nepřesně vyjádřeného reliéfu je nutné používat hypsometrickou reprezentaci pokud možno co nejbližší $\mathrm{k}$ primárním zdrojům výškových dat.

Obr. 1 - Tři zpo̊soby interpolace používané $\mathrm{k}$ transformaci hodnot diskrétních DMR do spojitých povrchových modelů: a) proximální interpolace, b) lineární interpolace, c) interpolace kubických splajnů

Obr. 2 - Citlivost reliéfu $v$ orientaci svahů odvozených ze dvou odlišných DMR vygenerovaných nad stejným zdrojem dat

(Author is with Department of Geoinformatics, Faculty of Science, Palacky University, tr. Svobody 26, 77146 Olomouc,Czechia; e-mail:vitek@risc.upol.cz.) 